\title{
Costs of treating skin lesions in Primary Health Care
}

\author{
Custos do tratamento de lesões cutâneas na Atenção Primária à Saúde
}

\section{Costos del tratamiento de lesiones cutáneas en Atención Primaria de Salud}

\author{
Daniel Nogueira Cortez ${ }^{1, *}$, Juliano Teixeira Moraes ${ }^{1}$, Isabela Rodrigues Ferreira ${ }^{1}$, Elton Libério Silva ${ }^{1}$, \\ Fernanda Moura Lanza ${ }^{1}$
}

ORCID IDS

Cortez DN (D) https://orcid.org/0000-0002-4644-274X

Moraes JT (D) https://orcid.org/0000-0002-11 09-962X

Ferreira IR (iD https://orcid.org/0000-0002-8514-2475

Silva EL (D) https://orcid.org/0000-0002-0549-0446

Lanza FM (D) https://orcid.org/0000-0001-8250-180X

\section{HOW TO CITE}

Cortez DN; Moraes JT; Ferreira IR; Silva EL; Lanza FM. Costs of treating skin lesions in Primary Health Care. ESTIMA, Braz. J. Enterostomal Ther. 2019, 17, e2419. https://doi.org/10.30886/estima.v17.824_IN

\begin{abstract}
Objective: To compare the cost of dressing with the use of conventional and advanced dressings in Primary Health Care. Method: Retrospective longitudinal study conducted in a municipality in the interior of Minas Gerais, Brazil, which followed 15 patients from admission to the healing of skin lesions to calculate treatment costs. Previous treatment up to the time of admission to the study was compared by processing the time and materials spent with the current treatment with advanced coverage. Results: In the conventional treatment, the average time of existence of the lesion before admission in the study was 620 days. The estimated total cost of all patients with daily change of conventional dressing was $\mathrm{R} \$ 101,030.58$ (US\$26,586.94). In the advanced coverage treatment modality, the average follow-up time was 151 days, resulting in a total cost of $R \$ 15,631.02$ (US $\$ 4,113.43$ ). The savings were over $\mathrm{R} \$ 85,000.00$ (US\$22,370.00). Conclusion: The cost of treatment with advanced coverages was seven times lower for the municipality, in addition to reducing the healing time for patients, allowing a shorter return to their work activities.
\end{abstract}

DESCRIPTORS: Wound healing; Wounds and injuries; Nursing; Enterostomal therapy.

\begin{abstract}
RESUMO
Objetivo: Comparar o custo na realização de curativos com o uso de coberturas convencionais e avançadas na Atenção Primária à Saúde. Método: estudo longitudinal retrospectivo realizado em um município de médio porte do interior de Minas Gerais, Brasil, que acompanhou 15 pacientes da admissão à cicatrização das lesões cutâneas para o cálculo dos custos do tratamento. Comparou-se o tratamento realizado anteriormente até o momento da admissão na pesquisa processando o tempo e materiais gastos com o tratamento atual realizado com coberturas avançadas. Resultados: no tratamento convencional, constatou-se tempo médio de 620 dias de existência da lesão anterior à admissão no estudo. Com a troca diária do curativo convencional, o custo estimado total de todos os pacientes foi no valor de $\mathrm{R} \$ 101.030,58$ (US\$26.586,94). Na modalidade de tratamento com coberturas avançadas, 0 tempo médio de acompanhamento foi de 151 dias, o que resultou em um custo total de $R \$ 15.631,02$ (US $\$ 4.113,43$ ). A economia foi de mais de R \$ 85,000.00 (US\$22.370,00). Conclusão: o custo do tratamento com coberturas avançadas foi sete vezes menor para o município, além de diminuir o tempo de cicatrização para os pacientes permitindo retorno mais breve para suas atividades laborais.
\end{abstract}

DESCRITORES: Cicatrização; Ferimentos e lesões; Enfermagem; Estomaterapia.

1.Universidade Federal de São João del-Rei - Curso de Enfermagem - Divinópolis (MG), Brazil

*Correspondence author: danielcortez@ufsj.edu.br

Received: 19 Nov 2019 | Accepted: 12 Dec 2019 


\section{RESUMEN}

Objetivo: comparar el costo del apósito con el uso de apósitos convencionales y avanzados en atención primaria de salud. Método: Estudio longitudinal retrospectivo realizado en un municipio del interior de Minas Gerais, Brasil, que siguió a 15 pacientes desde el ingreso hasta la curación de lesiones cutáneas para calcular los costos del tratamiento. El tratamiento anterior hasta el momento de la admisión al estudio se comparó procesando el tiempo y los materiales dedicados al tratamiento actual con cobertura avanzada. Resultados: en el tratamiento convencional, se verificó el tiempo promedio de existencia de la lesión antes del ingreso en el estudio de 620 días. Con el cambio diario del apósito convencional, el costo total estimado de todos los pacientes fue de R\$101.030,58 (US\$26.586,94). En la modalidad de tratamiento de cobertura avanzada, el tiempo de seguimiento promedio fue de 151 días, lo que resultó en un costo total de R\$15.631,02 (US\$ 4.113,43). Los ahorros fueron superiores a R\$ 85.000,00 (US\$22.370,00). Conclusión: el costo del tratamiento con coberturas avanzadas fue siete veces menor para el municipio, además de reducir el tiempo de curación para los pacientes, permitiendo un retorno más corto a sus actividades laborales.

DESCRIPTORES: Cicatrización de heridas; Heridas y traumatismos; Enfermería; Estomaterapia.

\section{INTRODUCTION}

The skin lesion is characterized by rupture of tissue integrity, which leads to changes in anatomical and physiological functions of affected tissues ${ }^{1}$. When they stagnate, or there is a failure in one of the stages of the healing process, they are considered a chronic condition, they increase the expenses in their treatment and interfere in the quality of life of the person with skin lesion ${ }^{2}$.

In the Brazilian Primary Health Care (PHC) service, the lesions found are generally of a long evolution. They require a high frequency of dressings by the traditional method often used, interfering in the patient's quality of life and productivity, representing a financial burden to the health system ${ }^{3,4}$. In this sense, the high costs in the treatment of skin lesions urge projects directed to the effectiveness of the actions developed by $\mathrm{PHC}$ managers ${ }^{4}$. It is known that public resources made available for health are insufficient, which requires better management and reduction of costs with the introduction of technologies and intelligence for the care and prevention of diseases ${ }^{5}$.

Especially in the care of skin lesions, technological advances have launched new products of proven costeffectiveness. Thus, they provide less frequency in dressing changes and consequently less pain, less risk of contamination and infection by the dressing techniques performed, or exposure to the environment $t^{4}$.

Several products are available for the treatment of skin lesions, which, with the technology employed and advances in the mode of action, allow them to be called advanced covers. These dressings are interactive, allow the maintenance of the temperature near the body temperature, promote the impermeability, and help the angiogenesis, favoring, this way, the healing process ${ }^{6}$.
The different characteristics of lesions and the variable therapeutic response require that health professionals, especially the nurse, can argue with public managers about the variety of covers and the cost-effectiveness of their use. It should be noted that in Brazil, it is still common to use conventional products that require daily changes in dressings. In this sense, the evaluation of advanced covers costs compared to conventional ones can subsidize the managers' decision for the best therapeutic method for the treatment of skin lesions in PHC.

From this context, the objective of this study was to compare the cost of the performance of dressings with the use of conventional and advanced covers in PHC.

\section{METHODS}

This is a retrospective longitudinal study using information from medical records of people with skin lesions.

Dressings with conventional covers were considered those that use only gauze, $0.9 \%$ saline solution (SS), procedure gloves, bandage, and some kind of dailychange ointment. The dressings with advanced covers were those that use besides gauze, SS $0.9 \%$ and procedure gloves, interactive covers such as hydrocolloid, calcium alginate, polyurethane foam, among others that allow change with less frequency.

The study was conducted in a Basic Health Unit of a municipality of 230,000 inhabitants located in the Midwest of Minas Gerais, Brazil, based on a research project that aimed at implementing the use of these covers as a function of cost analysis. 
The sample was of convenience and consisted of 15 patients with skin lesions treated in this health service, under the care of the researchers and who obtained complete healing in the years of 2013 to 2016. All participants in the research performed conventional dressings until the switch to advanced covers.

It should be noted that complete healing was given as a criterion for inclusion in order to establish a comparison parameter for the basis of the cost estimate. This justifies the data collection time of three years since the patients did not start the dressings at the same time. Altogether, 380 dressings were performed with an average time of 134 days from admission to healing.

The frequency of procedures varied according to the characteristics of the lesions and the type of covers used. A nursing consultation was performed for all participants of the survey at admission. Throughout the healing follow-up period, all participants were accompanied by professional nurses. Each subsequent new evaluation was performed, and the following information related to the lesion was recorded: the condition of the tissue and perilesional skin, presence of exudate, odor, pain, infection, edema, and products used.

For cost estimation and before and after comparison, two costs were estimated: conventional covers costs (CCC) and advanced covers costs (ACC).

For the CCC, the time of existence of the lesion in days registered in the health unit's medical records until the moment of admission to the study and the average cost registered for a dressing of this nature were considered. In this estimate, the minimum quantity of materials routinely used in the health units of the municipality for conventional dressings was: one $250 \mathrm{ml}$ saline solution bottle, two procedure gloves, four packs of gauze, and two $12 \mathrm{~cm}$ bandages. These materials represented a cost of R\$10.86/day (US\$2.66). It is noteworthy that the conventional dressing requires daily change. The cost in Brazilian currency (reais), but also in U.S. dollars, is justified as it is considered an international reference currency.

Therefore, to calculate the cost with the conventional dressing performed before the survey intervention, the total number of days that each injury received a daily dressing until the day of admission in the survey was considered multiplied by the value of $R \$ 10.86$ (US\$2.66), as in Eq. 1:
$\mathrm{CCC}=$ Number of days of conventional dressings Cost of conventional daily dressing

For the ACC, the reliable record of materials used in each dressing was considered, and their cost calculated. The advanced technology covers used: plate calcium and sodium alginate, silver activated carbon, plate hydrocolloid, hydrogel, transparent film, Unna's boot, and essential fatty acids for skin lubrication. These dressings also used gauzes, bandages, and saline solution for hygiene. All the materials used were registered in the records. As these covers allowed a less frequent change and the choice of treatment could be changed according to the evolution of the lesion, the value of the products used in each service was accounted for, and the actual total cost of treatment was obtained at the end of the treatment (Eq. 2).

ACC $=$ Daily cost $1+$ Daily cost $2+$ Daily cost $n$

The values considered for registration of each product were based on the 2019 municipality's bidding price quotation (Table 1 ).

Data processing for this survey was done using the software Microsoft Office Excel 2013, and descriptive analysis using the software Statistical Package for the Social Sciences (SPSS) 20.0.

The research followed national and international ethical parameters for research with human beings and was approved by an ethics committee, according to CAAE 07330012.8.0000.5545. All participants in this study agreed to participate and signed the free and informed consent term. The right to assistance was also assured, regardless of participation.

\section{RESULTS}

The sample consisted of 15 patients, 8 (53.3\%) male, most of them retired (87.5\%), 12 married (75\%), 9 with incomplete primary education $(56.2 \%)$, and the mean age was 66 years, standard deviation of 13.17. They all had basic sanitation in their homes. Hygiene conditions at the time of the interview were considered regular for $75 \%$ (12). Regarding life habits and previous conditions, $13(81.3 \%)$ patients consumed alcohol, 3 (18.8\%) were 
smokers. Hypertension was the most commonly found pathology (10,62.5\%), followed by diabetes mellitus (4.25\%).

Regarding the characteristics of the lesions, they were categorized according to their etiologies, with $9(60.0 \%)$ venous, $2(13.3 \%)$ neuroischemic, 1 (6.7\%) ischemic,

Table 1. Conventional and advanced technology materials values based on price quotation

\begin{tabular}{|c|c|}
\hline Materials & $\begin{array}{l}\text { Value in } \\
\text { Brazilian real and } \\
\text { US dollar }\end{array}$ \\
\hline Procedure gloves (unit) & $\mathrm{R} \$ 0.15$ (US\$ 0.037) \\
\hline Sterile gauze compress (unit) & $\mathrm{R} \$ 1.20$ (US\$ 0.29) \\
\hline Saline solution $0.9 \% 250 \mathrm{ml}$ & $\mathrm{R} \$ 2.72$ (US\$ 0.67) \\
\hline Crepe tape & $R \$ 3.29$ (US\$ 0.81$)$ \\
\hline Crepe bandage $10 \mathrm{~cm}$ & $\mathrm{R} \$ 1.79$ (US\$ 0.44) \\
\hline Crepe bandage $12 \mathrm{~cm}$ & $\mathrm{R} \$ 2.20$ (US\$ 0.54) \\
\hline Crepe bandage $15 \mathrm{~cm}$ & $\mathrm{R} \$ 2.80$ (US\$ 0.69$)$ \\
\hline Crepe bandage $20 \mathrm{~cm}$ & $\mathrm{R} \$ 5.72$ (US\$1.40) \\
\hline Sterile needle $40 \times 12 \mathrm{~mm}$ & $\mathrm{R} \$ 0.15$ (US\$0.037) \\
\hline Lâmina de bisturi estéril (unidade) & $\mathrm{R} \$ 0.40$ (US\$ 0.098$)$ \\
\hline Sterile scalpel blade (unit) & $\mathrm{R} \$ 17.60$ (US\$ 4.31) \\
\hline Essential fatty acid (EFA) $200 \mathrm{ml}$ (bottle) & $\mathrm{R} \$ 11.90$ (US\$2.92) \\
\hline Unna's boot (unit) & $\mathrm{R} \$ 17.35$ (US\$4.25) \\
\hline Hydrocolloid plate 10×10 cm (unit) & $\mathrm{R} \$ 7.98$ (US\$1.96) \\
\hline Alginate hydrogel $(50 \mathrm{ml})$ & $\mathrm{R} \$ 17.70$ (US\$ 4.34) \\
\hline Transparent film $100 \mathrm{~cm}$ (unit) & $\mathrm{R} \$ 6.58$ (US\$ 1.61) \\
\hline
\end{tabular}

1 (6.7\%) pressure, $2(13.3 \%)$ trauma. Regarding the location, 8 (50\%) were in the malleolus region, $3(18.8 \%)$ in the middle third of the lower limbs, 2 (13.3\%) in the back of the foot, 1 (6.7\%) in the calcaneus, and 1 (6.7\%) in the toe amputation stump.

In the conventional treatment, the meantime of the lesion before admission to the study was 620 days. With the conventional dressing daily change, the estimated total cost of all patients was R $\$ 101,030.58$ (US\$26,586.94). It should be noted that the actual cost can probably be higher since ointments and other drugs associated with the conventional dressing are usually used, determining the possibility of higher consumption of materials than the minimum estimated by the research.

In the treatment modality with advanced covers, the average follow-up time was 151 days, varying between 37 and 738 days, which resulted in a total cost of $\mathrm{R} \$ 15,631.02$ (US\$ 4,113.43). This cost covered the number of times the user changed the dressing and not the time in days of healing. It should be noted that the number of dressing changes in this modality varied according to the particularities of the materials and the injury.

In both dressings, the cost of direct labor was not calculated.

Table 1. Time of existence of each patient's injury (in days), the cost in reais (total also in dollars) of conventional and advanced treatment, and some dressing changes.

\begin{tabular}{|c|c|c|c|c|c|}
\hline Number & $\begin{array}{l}\text { Dressing time with } \\
\text { conventional covers } \\
\text { (days) }\end{array}$ & $\begin{array}{l}\text { Investment in } \\
\text { conventional } \\
\text { covers }\end{array}$ & $\begin{array}{l}\text { Dressing time with } \\
\text { advanced covers } \\
\text { (days) }\end{array}$ & $\begin{array}{c}\text { Number of dressing } \\
\text { changes with advanced } \\
\text { covers }\end{array}$ & $\begin{array}{l}\text { Investment in } \\
\text { advanced covers }\end{array}$ \\
\hline 1 & 191 & $R \$ 2,074.26$ & 91 & 18 & $R \$ 280.38$ \\
\hline 2 & 120 & $\mathrm{R} \$ 1,303.20$ & 44 & 10 & $R \$ 382.27$ \\
\hline 3 & 150 & $\mathrm{R} \$ 1,629.00$ & 68 & 13 & $R \$ 787.76$ \\
\hline 4 & 138 & $\mathrm{R} \$ 1,498.68$ & 240 & 49 & $\mathrm{R} \$ 337.01$ \\
\hline 5 & 30 & $\mathrm{R} \$ 325.80$ & 69 & 13 & $\mathrm{R} \$ 281.31$ \\
\hline 6 & 90 & $R \$ 977.40$ & 43 & 9 & $\mathrm{R} \$ 123.92$ \\
\hline 7 & 45 & $\mathrm{R} \$ 488.70$ & 113 & 14 & $R \$ 387.11$ \\
\hline 8 & 60 & $R \$ 651.60$ & 38 & 9 & $R \$ 110.76$ \\
\hline 9 & 60 & $R \$ 651.60$ & 95 & 21 & $\mathrm{R} \$ 592.62$ \\
\hline 10 & 270 & $\mathrm{R} \$ 2,932.20$ & 164 & 41 & $R \$ 1,922.85$ \\
\hline 11 & 713 & $\mathrm{R} \$ 7,743.18$ & 304 & 28 & $\mathrm{R} \$ 1,538.49$ \\
\hline 12 & 7301 & $R \$ 79,288.86$ & 738 & 105 & $\mathrm{R} \$ 7,704.46$ \\
\hline 13 & 90 & $\mathrm{R} \$ 977.40$ & 102 & 15 & $R \$ 805.37$ \\
\hline 14 & 18 & $R \$ 195.48$ & 126 & 29 & $R \$ 323.34$ \\
\hline 15 & 27 & $R \$ 293.22$ & 37 & 6 & $R \$ 53.37$ \\
\hline Total & 9303 & $\begin{array}{l}R \$ 101,030.58 \\
\text { US\$ } 26,586.94\end{array}$ & 2272 & 380 & $\begin{array}{l}\mathrm{R} \$ 15,631.02 \\
\text { US } \$ 4,113.43\end{array}$ \\
\hline
\end{tabular}




\section{DISCUSSION}

The participants in the research were mostly elderly, with an average age of 66 years. It is known that aging is associated with decreased skin elasticity and vascularization, which favors the appearance of injury. At the same time, with tissue alterations typical of aging, the older person is more prone to comorbidities, immobility, and malnutrition ${ }^{2,3}$.

The proportion of males is slightly higher than females, which shows a small difference in the incidence of skin lesions between the sexes. According to literature and other studies, sex is not a determining factor in the presence of skin lesions ${ }^{1,7}$.

Regarding the educational level, most of the participants have incomplete primary education and are retired with a monthly income of one minimum wage. The lower educational level may interfere with the understanding of the guidelines, which reflects in the promotion of self-care with the lesion ${ }^{8}$. Low income can influence the quality of life, such as access to food that contributes to healing, hygiene conditions, and adequate housing ${ }^{9}$.

The current treatment time took on average 620 days, in contrast to the special treatment with an average of 151 days, which considerably reduces dressing changes, the patient's frequency in the Health Unit, and the time spent by the professional in making dressings. The choice and access to advanced covers allow for less frequent dressing changes that benefit the patient with accelerated healing, reduced pain, exudate, and odor ${ }^{10,11}$. Another aspect is that the nurse gets free time for other activities, besides getting the discharge for cure with less time ${ }^{12}$. A systematic review analyzing the cost of wound treatment states that in addition to increasing the healing rate, adequate treatment with advanced covers can also be cost-effective, as it reduces the number of dressing changes required or the time required to apply the dressing ${ }^{13}$.

The study showed estimated savings of approximately $\mathrm{R} \$ 85,000.00$ (US $\$ 22,370.00$ ) for only 15 users, representing $85 \%$ savings for the public service. Based on the information provided by the municipality (with 230,000 inhabitants) in which this study was conducted, there are approximately 200 people registered with skin lesions, which would generate an expenditure of approximately R $\$ 1,350,000.00$ (US\$ 355,000.00) with the use of conventional covers without healing. By adopting effective healing measures as proposed in this survey, the expense would be approximately $\mathrm{R} \$ 208,000.00$ (US\$ 55,000.00), representing savings for the municipal manager of around $\mathrm{R} \$ 1.142 .000,00$ (US\$ 300,000.00).

Data on the prevalence of skin lesions are scarce in Brazil and the world. A systematic review with recent meta-analysis showed variation in the prevalence by characteristics of the lesions, considering the prevalence of 2.21 per 1,000 inhabitants for mixed lesions and 1.51 per 1,000 inhabitants for venous lesions ${ }^{14}$.

Advanced covers have a higher cost when analyzed in isolation, but considering the reduced number of changes and the therapeutic properties of this cover type, the cost of treatment is about seven times lower when compared to conventional cover. In addition to these benefits, the dressings with interactive covers allow an improvement in the quality of life for the patients, with an acceleration of healing and, at the same time, return to work and social activities, previously restricted by the presence of the lesion ${ }^{4,6}$.

It should be noted that advanced covers may have their costs increased, even higher than conventional covers, if the professional shows unpreparedness for their handling and indication, as well as incorrect techniques for implementation and management of dressings and skin lesions. It should be noted that in cases of palliative care, where cure is not the main objective, the cost of the dressing is relativized according to the benefit of the advanced covers in terms of reducing pain, odor, excess exudate, among other advantages ${ }^{15}$.

As a limitation of this study, the number of scientific productions dealing with the cost of treatment of skin lesions in Primary Health Care still needs to be advanced, as most publications are of secondary care or outpatient reference. This is a factor that justifies and reinforces the importance of this type of research. Moreover, the study did not account for other materials spent on conventional dressings, such as ointments, other types of covers, necessary materials, among others, in addition to underestimating the materials spent considered minimal, which would increase the cost of conventional treatment. 
The recording of materials spent in the conventional method by the health units of the municipality is absent, which limited the calculations of the study. In order to mitigate this limit, the number of materials, types, and therefore the cost per conventional dressing, were underestimated. Another limiting factor was the length of time the lesion existed before entry into the project, which was reported by the patient himself, limited by memory bias. Finally, the time of existence of the lesion for calculation in the conventional dressing could be longer than informed, since it was interrupted with the beginning of the advanced dressings. Therefore, if the patient did not undergo the intervention for the advanced dressing, he could remain with the lesion until the present day, which would considerably increase the costs with the conventional treatment for the municipality.

\section{CONCLUSION}

The cost of treatment with advanced covers was approximately seven times lower when compared to the modality with conventional covers, representing a saving of more than $\mathrm{R} \$ 85,000.00$ (US $\$ 22,370.00$ ) for the municipality. It should be noted that the treatment time in the modality with advanced covers is shorter than the dressing with conventional covers and allows patients to return to their work activities more quickly. This therapeutic option also provides higher availability of time for professionals, since the dressings are not performed daily, which further increases savings to the public coffers. The results of this study subsidize the decision of municipal management to adopt more effective and less expensive practices in the care of people with skin lesions.

\section{ACKNOWLEDGMENTS}

Pró-Reitoria de Extensão da Universidade Federal de São João del-Rei, Proext-MEC and Secretaria Municipal de Saúde de Divinópolis/MG.

\section{AUTHORS' CONTRIBUTION}

Conceptualization, Cortez DN, and Lanza FM; Methodology, Cortez DN, Moraes JT, Ferreira IR, Silva EL, and Lanza FM; Investigation, Cortez DN, and Lanza FM; Writing - Original Draft, Cortez DN, Moraes JT, Ferreira IR, Silva EL, and Lanza FM; Writing - Review and Editing, Cortez DN and Moraes JT; Supervision, Cortez DN.

\section{REFERENCES}

1. Gonzalez ACO, Costa TF, Andrade ZA, Medrado ARAP Wound healing - A literature review. An Bras Dermatol. 2016;91(5):614-20. https://doi.org/10.1590/abd18064841.20164741

2. Järbrink $K, N i$, Sönnergren $H$, Schmidtchen $A$, Pang $C$, Bajpai R, et al. Prevalence and incidence of chronic wounds and related complications: a protocol for a systematic review. Systematic Reviews. 2016;5(152):1-6. https://doi. org/10.1186/s13643-016-0329-y

3. Vieira CPB, Furtado AS, Almeida PCD, Luz MHBA, Pereira AFM. Prevalência e caracterização de feridas crônicas em idosos assistidos na atenção básica. Rev Baiana Enferm. 2017;31(3):1-13. https://doi.org/10.18471/rbe.v31i3.17397

4. Vieira CPB, Araújo TME. Prevalence and factors associated with chronic wounds in older adults in primary care. Rev Esc Enferm USP. 2018;52:1-8. https://doi.org/10.1590/S1980220X2017051303415
5. Saldiva PHN, Veras M. Gastos públicos com saúde: breve histórico, situação atual e perspectivas futuras. Estud Av. [online]. 2018;32(92):47-61. https://doi.org/10.5935/01034014.20180005

6. Dhivya S, Padma W, Santhini E. Wound dressings - a review; Biomedicine (Taipei). 2015;5(4):22.

7. Silva CFR, Santana RF, Oliveira BGRB, Carmo TG. High prevalence of skin and wound care of hospitalized elderly in Brazil: a prospective observational study. BMC Res Notes. 2017;10(81):1-6. https://doi.org/10.1186/s13104-017-2410-6

8. Squizatto RH, Braz RM, Lopes AO, Rafaldini BP, Almeida DB, Poletti NAA. Perfil dos Usuários atendidos em ambulatório de cuidado com feridas. Cogitare Enferm. 2017;22(1):1-9. https://doi.org/10.5380/ce.v22i1.48472

9. Oliveira FP, Oliveira BGRB, Santana RF, Silva BP, Candido JSC. Classificações de intervenções e resultados de enfermagem em pacientes com feridas: mapeamento 
cruzado. Rev Gaúcha Enferm. 2016;37(2):1-9. https://doi. org/10.1590/1983-1447.2016.02.55033

10. Chamanga E. Effectively managing wound exudate. $\mathrm{Br} J$ Community Nurs. 2015;20(Supl. 9):S8-S10. https://doi. org/10.12968/bjcn.2015.20.Sup9.s8

11. Blacklow SO, Li J, Freedman BR, Zeidi M, Chen C, Mooney DJ. Bioinspired mechanically active adhesive dressings to accelerate wound closure. Science Advances. 2019;5(7):110. https://doi.org/10.1126/sciadv.aaw3963

12. Lindsay E, Renyi R, Wilkie $P$, Valle F, White W, Maida V, et al. Patient-centred care: a call to action for wound management. J Wound Care. 2017;26(11):662-77. https:// doi.org/10.12968/jowc.2017.26.11.662
13. Al-Gharibi KA, Sharstha S, Al-Faras MA. Cost-Effectiveness of Wound Care: A concept analysis. Sultan Qaboos Univ Med J. 2019;18(4):e433-9. https://doi.org/10.18295/ squmj.2018.18.04.002

14. Martinego $L$, Olsson M, Bajpai R, Soljak M, Upton Z, Schmidtchen A, et al. Prevalence of chronic wounds in the general population: systematic review and meta-analysis of observational studies. Ann Epidemiol. 2019;29:8-15. https:// doi.org/10.1016/j.annepidem.2018.10.005

15. Woo KY, Krasner DL, Kenned B, Wardle D, Moir O. Palliative Wound Care Management Strategies for Palliative Patients and Their Circles of Care. Adv Skin Wound Care. 2015;28(3):130-40. https://doi.org/10.1097/01. ASW.0000461116.13218.43 